\title{
Participation of Women Farmers in Agroforestry Practices in the Jaman South Municipality, Ghana
}

\author{
Francis Diawuo \\ Department of Environment and Resource Studies, \\ University for Development Studies, Ghana \\ Enoch Akwasi Kosoe \\ (Corresponding Author) \\ Department of Environment and Resource Studies, University \\ for Development Studies, Ghana ekosoe@uds.edu.gh \\ Dzigbodi A. Doke \\ Department of Environment and Sustainability, \\ University for Development Studies, Ghana \\ DOI//http://dx.doi.org/10.4314/gjds.v16i2.13
}

\begin{abstract}
Despite the key roles of women in agroforestry systems, their contributions usually go unnoticed in male - dominated societies. This study was conducted in the Jaman South Municipality of Ghana to examine the forms and levels of women's participation in agroforestry systems. The study used a concurrent mixed method design to collect data from 204 women farmers. It employed Agarwal's typology of participation to describe the forms of women's participation. The findings revealed that majority (85.3\%) of the women farmers were active in the practice of agroforestry. Scattered trees on farmlands, alley cropping, taungya, and home-gardens were the main forms of agroforestry being practiced by the women farmers. Their participation was high in all farm management activities, except in the application of agro-chemicals and spraying of crops. The forms of women participation in agroforestry were found to conform to all the stages of Agarwal's typology of participation. Lack of extension programmes and multiple domestic responsibilities were the main constraints to their participation in agroforestry practices. The study recommends training of women to volunteer as extension officers to enhance extension services delivery.
\end{abstract}


Keywords: Alley Cropping, Farmers, Farm Management, Female, Household, Taungya, Participation

\section{INTRODUCTION}

In time past, when population was low and agricultural land was in abundance, farming practices such as shifting cultivation and bush fallow were able to sustain soil fertility and crop yields (Opoku-Mensah, 2015), by nourishing the soils before cropping. However, the increasing pressure on fertile lands because of population increase and unsustainable farming systems has resulted in limited availability of fertile lands and soil infertility respectively. While the global population is expected to be over 9 billion by 2050 (Food and Agriculture Organisation (FAO), 2010), the population of Ghana has expectedly been following the increasing trend over the years. With a population of about 8 million in the 1970s, Ghana's population has increased massively to more than 24 million in 2010, with a population growth rate of 3\% per annum (Ghana Statistical Service (GSS), 2011). The implications of this increase are the strains on resources, especially forest and soil fertility.

Meeting the challenges of deforestation and loss of soil fertility, the historical practice of mixing food crops with tree crops on the same piece of land, has been advanced as agroforestry to curb land and forest management challenges. Agroforestry systems are widely considered as a promising solution to land degradation problems (Poudyal, 2009). It helps address issues of forest cover loss, soil infertility, crop loss, and to enhance food security and improve conditions of farmers (Atangana et al., 2014). The adoption and practice of agroforestry can also lead to improved crop and livestock production and also serve as a major source of cash income to households (Parwada et al., 2010). It can also help in climate change mitigation, since it has the potential of creating carbon sink that removes carbon dioxide $\left(\mathrm{CO}_{2}\right)$ from the atmosphere, or the maintenance of existing carbon in the vegetation (Smith, 2010; Intergovernmental Panel on Climate Change [IPCC], 2012).

Globally, agroforestry systems have been classified under structural; functional; socio-economic; and ecological basis (Vira et al., 2015). These can be grouped into agri-silviculture, silvopastoral and agri-silvopastoral. In agri-silviculture, farmers plant tree crops together with food crops and vegetables on the same agricultural landscape. This system is commonly referred to as mixed cropping since it contains both food crops and tree crops or woody perennials. The Silvopastoral system is the practice where trees, forage and domesticated animals are integrated in an agricultural system for mutual benefits. The system is considered as an alternative for the restoration of soil fertility, meeting food security needs, and income diversification (Mauricio et al., 2019). On the other hand, the agri-silvopastoral 
is the practice of integrating food crops, trees and domesticated animals in an agricultural system.

Across Africa, women's participation in agroforestry is integral to the success of the practice (Kiptot \& Franzel, 2012), as they play a crucial role in most production systems in the household. Women play an active role in the agricultural sector and constitute the bulk of global agricultural producers (Mulugeta \& Amsalu, 2014). However, they face various constraints and challenges that limit their capacities to achieve optimal production and agricultural development (Degrande \& Arinloye, 2014). Their prospects in agroforestry are restricted to activities that men do not value. According to Kiptot and Franzel (2012), agroforestry activities are distinguished based on gender. Thus, men tend to concentrate on trees of economic value while women favour multiuse trees.

Studies (see in World Bank, 2012; Kilic et al., 2014) have continuously identified gender-based gaps in agricultural production. Accessing adequate useful resources and variation in individual characteristics (Kinkingninhoun-Medagbe et al., 2010) have been identified to be the main drivers of these gender gaps. In Ghana, tree farming and decision-making at the household level are not adequately documented. Presumably, the household head is the key decision-making maker, who in most cases is the husband (Deere et al., 2012; Rogan, 2013), hence it is imperative to understand farm decision-making dynamics in the household.

In the Jaman South Municipality, men involved in agriculture have more access to and control over resources such as land, labour and household decision making powers than women (Jaman South Municipal Assembly [JSMA], 2010). Like any other Akan community, the families in the Municipality observe the matrilineal succession in which women traditionally do not have right to inherit land. Although this is gradually changing and in most societies, women are beginning to own land by purchase, the former is still predominant and serves as a constraint to women's active involvement agricultural related projects. In the quest to know the level of women's participation and unravel the challenges to their participation in agroforestry, the study sought answers to the following questions:

i. What are the agroforestry technologies practiced in the area?

ii. What is the level of women's participation in agroforestry practice in the area?

iii. What are the constraints to women's participation in agroforestry practice in the area? 


\section{Typology of Participation: a Conceptual Review}

Stakeholder participation in contemporary times is necessary for effective development. However, it is not a one size fits all principle. Instead, participation varies with participants' ability to partake in the matter in context and how participatory the process is being facilitated. In the literature, authors distinguish different degrees, shapes, levels, types and dimensions of participation (Agarwal, 2001). From the development initiatives standpoint, participation broadly ranges from a mere involvement of people, to an autonomous decision - making at the local level. Participation is thus classified based on the concept of capacity to participate in an intervention (Agarwal, 2001).

This study adopts Agarwal (2001:1624) typology of participation to show the levels (movement from lower to a higher level) of involvement of women in agroforestry activities. The ability of an individual to move below or up a level is an indication of the activeness of individual. From nominal participation, where members of a group may not have influence on the group, participation moves from passive to interactive, where members become active and with voice and influence in the group's decisions as shown in Table 1.

Table 1: Typology of participation

\begin{tabular}{|l|l|}
\hline Level/ Form of Participation & Characteristic Features \\
\hline Nominal Participation & Member in the group. \\
\hline Passive Participation & $\begin{array}{l}\text { Being informed of decisions ex post facto: or attending } \\
\text { meetings and listening in on decision making without } \\
\text { speaking up. }\end{array}$ \\
\hline Consultative Participation & $\begin{array}{l}\text { Being asked an opinion on specific matters without } \\
\text { guarantee or influencing their decisions }\end{array}$ \\
\hline Activity/ Specific participation & $\begin{array}{l}\text { Being asked to (or volunteering) undertake specific } \\
\text { task. }\end{array}$ \\
\hline Active Participation & Expressing opinions, whether or not solicited \\
\hline Interactive (Empowerment) Participation & Having voice and influence in group's decision \\
\hline
\end{tabular}

Source: Adopted from Agarwal (2001)

Almost all the various typologies of participation place self-mobilisation as the highest position, but, they fail to solve all problems (Adom, 2012). It can therefore be deduced from Agarwal's (2001), that even interactive participation (which is seen as the topmost) has limits of socio-economic, inequality and power relations within the group or community. Relatedly, women's participation in agroforestry, even if found to be 'interactive', would have issues of power relations (between husband 
and wife in the household), inequality (such as access to land), which may still limit their participation, seemingly due to cultural relations.

The review has shown in some cases that women are active in the adoption and practice of agroforestry, however in other cases their participation is limited. While the study aimed to document women's increasing participation in the Jaman South Municipality, Agarwal's typology of participation enabled the identification and categorisation of women's participation in agroforestry as either interactive, active, activity or passive, keeping in mind the social, economic, and cultural constraints.

\section{MATERIALS AND METHODS}

The Jaman South Municipality has a total land area of about 755.37290 square kilometres $\left(\mathrm{km}^{2}\right)$. It is located between latitudes $7^{\circ} 20^{\prime} \mathrm{N}$ and $7^{\circ} 50^{\prime} \mathrm{N}$ and longitudes $2^{\circ} 37^{\prime} \mathrm{W}$ and $2^{\circ} 58^{\prime} \mathrm{W}$ (GSS, 2014). It shares borders with the Jaman North District to the north, Berekum Municipal Assembly to the south-east, Dormaa Municipal Assembly to the south-west and Ivory Coast to the west (JSMA, 2010), as shown in Figure 1.

\section{Figure 1: Map of the study area}

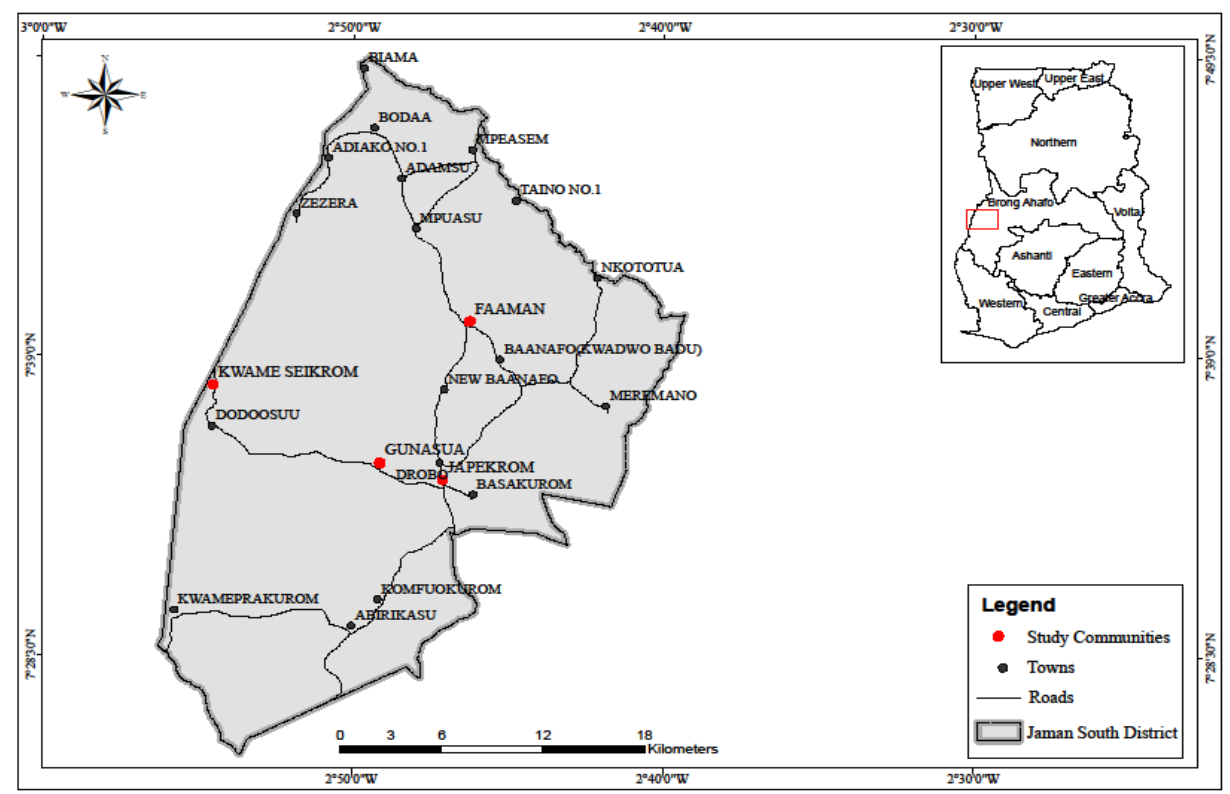

Source: Authors' construct (2017) 
The study employed the concurrent mixed method approach based on pragmatism, using the interpretivist perspective (Gentle et al., 2014). This design was used because of its ability to use both qualitative and quantitative approaches in gathering, analysing and presenting data. Using the random number generation in Microsoft's Excel, four communities (Japekrom, Gonasua, Faaman and Kwameseikrom) were selected (Figure 1). Stratified sampling was used in the selection of households. The study communities were grouped into sections or strata by their respective Town Councils. Japekrom was grouped into 10 sections, Gonasua 8 sections, Faaman 4 sections and Kwameseikrom 4 sections. Using these sectins, housing units were randomly selected using Microsoft Excel. In a house of two or more households, only one was selected for interview, based on convenience of the household.

A household survey ( $n=204$ respondents) was used to generate the quantitative data. Questionnaire were administered to women farmers in the selected households. In a household of two or more women farmers, only one was selected for interview, based primarily on the practice of agroforestry. The questionnaire included both close and open-ended questions, to give respondents the opportunity to express their views on the issues under discussion. To get information on the extent of women's participation in farm management activities, respondents were asked using a five-point continuum namely: 'Always', 'Often', 'Occasionally', 'Rarely', and 'Never', to indicate the frequency of their participation. Also, questions were asked as to whether women's opinions were considered, and if they were only consulted or had the final say in decisions concerning farm management in the household. In addition, qualitative data were collected using Focus group discussions (FGDs) ( $n=$ 4 events with 12 participants each). Also, in-depth interviews with key informants from the Ministry of Food and Agriculture (MoFA) and Forest Services Division (FSD) of the Forestry Commission were conducted.

Data collected through questionnaire were transferred into Statistical Package for the Social Sciences (SPSS) version 20.0 software, which was used to conduct a Pearson's correlation coefficient test to ascertain the relationship between respondents' demographic characteristics and their practice of agroforestry. To measure the form/extent of women's participation in agroforestry management activities, the index of participation was calculated based on respondents' participation in agroforestry activities. Index of participation (Table 2a) was computed based on a formula adapted from Adhikari (1996) by Kamnap (2003). 
Table 2a: Computation of index of participation

\begin{tabular}{|l|l|l|l|l|}
\hline Always & Often & Occasionally & Rarely & Never \\
\hline 1 & 0.8 & 0.6 & 0.4 & 0.2 \\
\hline
\end{tabular}

Source: Authors' construct

Participation indices were computed as follows: Computation of frequency of participants (n) in a particular activity. Division of frequency by the total number of respondents $(\mathrm{N})$. The formula adopted is: $I P=n / N$; Where; $I P$ - Index of participation in an activity; $n$ - Frequency of respondents participating in an activity; $N$ - Total number of respondents. The Index of Participation values is interpreted on a scale of o-1; where zero means stakeholders have no chance of participating and 1 means, always participating.

However, one important criticism of the formula is that it only considers values that are even. This study has modified this to include all possible values between o-1, to indicate the level of participation in an activity (Table $2 \mathrm{~b}$ ).

Table 2b: Computation of the level of participation

\begin{tabular}{|l|l|l|l|l|}
\hline Very High & High & Average & Low & Very Low \\
\hline $0.9-1$ & $0.7-0.8$ & $0.5-0.6$ & $0.3-0.4$ & $0-0.2$ \\
\hline
\end{tabular}

Source: Kamnap (2003)

An increase in values from o-1 implies an increasing participation level of women with respect to a specific agroforestry management activity.

The qualitative data gathered through key informant interviews on women's participation in agroforestry were analysed using content analysis based on themes and topics. Data in the form of audio recording were transcribed into English from the local dialect and the content of discussions were then analysed and presented in the form of narrations and quotations alongside the findings from the questionnaire.

\section{RESULTS AND DISCUSSION}

\section{Agroforestry Adoption and Practice among Respondents}

The study revealed that more than two-thirds (85\%) of the women interviewed were active in the adoption and practice of agroforestry. Across the communities, the adoption and practice of agroforestry was high in Kwameseikrom, (95.5\%) than Japekrom (82.7\%) (Table 3). In Kwameseikrom for instance, at least one household 
in every house was practicing agroforestry. On the other hand, Japekrom had the highest number of respondents (17.3\%) not practicing agroforestry, relatively because of its urban status, coupled with other alternative means of livelihood such as trading, hair dressing, and dressmaking, among others.

Table 3: Women's participation in agroforestry

\begin{tabular}{|l|l|l|l|}
\hline Community & \multicolumn{2}{|l|}{ Status on Agroforestry Practice } & Total \\
& Yes No & \\
\hline Japekrom & $86(82.7)$ & $18(17.3)$ & $104(100.0)$ \\
\hline Gonasua & $43(84.3)$ & $8(15.7)$ & $51(100.0)$ \\
\hline Faaman & $24(88.8)$ & $3(11.2)$ & $27(100.0)$ \\
\hline Kwameseikrom & $21(95 \cdot 5)$ & $1(4.5)$ & $22(100.0)$ \\
\hline Total & 174 & 30 & 204 \\
\hline
\end{tabular}

Figures in parenthesis are percentages.

Source: Field survey (2018)

While it is true that land in urban areas is more valuable for building than farming, Satterthwaite (2007), posits that as urbanisation takes effect, the economically active population employed in the primary sector such as agriculture reduces and the service sector experiences an increase. The high level of participation in agroforestry across the communities is due to the fact that sale of crops (especially the tree crops), contributes to their household income. This reflects Ajayi et al. (2008) that, proceeds from agroforestry complements household livelihood and income.

Recounting why they were not practicing agroforestry, the respondents cited limited availability of land and time as their reasons. These women revealed that they were not natives to the communities they were residing in, hence getting access to land to farm perennial cash crops like cashew, cocoa or woody perennial was difficult. According to some landowners, they would rather give their land to settlers to plant food crops than tree crops. This is because some settlers after planting trees, tend to claim the land as theirs, apparently because the land was given out without any written agreement. This implies that some land owners were unwilling to give their lands to non-natives or settlers for agroforestry, for fear of their inability to take their lands back if the need be.

The study also found that certain socio-demographic characteristics influence the practice of agroforestry in the study area. Factors such as age and farm size were negatively and poorly correlated (at -.168 and -.584 respectively) with agroforestry practice in the study area (Table 4). These findings, however contradict findings of 
Dhakal et al. (2015) in Nepal, where age was found to influence the acceptance of new technology (such as agroforestry systems).

Table 4: Relationship between demographic characteristics and practice of agroforestry

\begin{tabular}{|l|l|}
\hline Demographic Characteristic & Practice of Agroforestry \\
\hline Age & $-.168^{\mathrm{NS}}$ \\
\hline Educational Status & $.147^{*}$ \\
\hline Household Status & $.213^{*}$ \\
\hline Farm Size & $-.584^{\mathrm{NS}}$ \\
\hline
\end{tabular}

Source: Field survey (2018)

Although one cannot refute the fact that older farmers may be more experienced than younger farmers and are weak to do labour intensive activities, age disparities did not affect women farmers' practice of agroforestry systems in the Municipality. In addition, farm size which refers to the preference of the farmers to grow much food for their household and for the market, was poorly correlated with agroforestry practice in the study area. This agrees with Edinam et al. (2013), that in the presence of low labour availability, farmers may be readier to adopt agroforestry practices such as enriched fallows and intercropping (but not necessarily increase or decrease farm size).

On the other hand, educational and household statuses had significant and positive correlation with the practice of agroforestry in the study area. Obviously, as people acquire more education or climb higher the educational ladder, they are more likely to adopt new agricultural technologies and interventions. This implies that, if more women in the study area had increased level of education (i.e. beyond Junior High School), they would better understand the need for the adoption of new agricultural technologies.

On the household status, more married women were practicing agroforestry (seemingly because they have the support of their husbands) than their single, divorced or widowed counterparts. These findings support the findings of Asfaw and Maggio (2015), that in developing countries of Africa, agricultural technology adoption, practice and outcome may depend on whether the decision-maker is the husband or the wife, as well as, if the decision-maker is also the household head.

\section{Agroforestry Systems and Technologies Practised}

The study revealed that agri-silviculture, which most farmers referred to as mixed cropping is the main system of agroforestry practiced in the study area. A key informant at the Ministry of Food and Agriculture (MoFA) supported this 
by stating that, "the only system practiced in the Municipality by both men and women is agri-silviculture. Silvo-pastoral and agri-silvi-pastoral are not practiced here because there are not many animals that would require one to go into that". Key technologies identified and practiced by farmers under agri-silviculture are; Scattered Trees on Farms (51.1\%) and Taungya (8.6\%) (Figure 2).

\section{Figure 2: Forms of agroforestry technologies practiced}

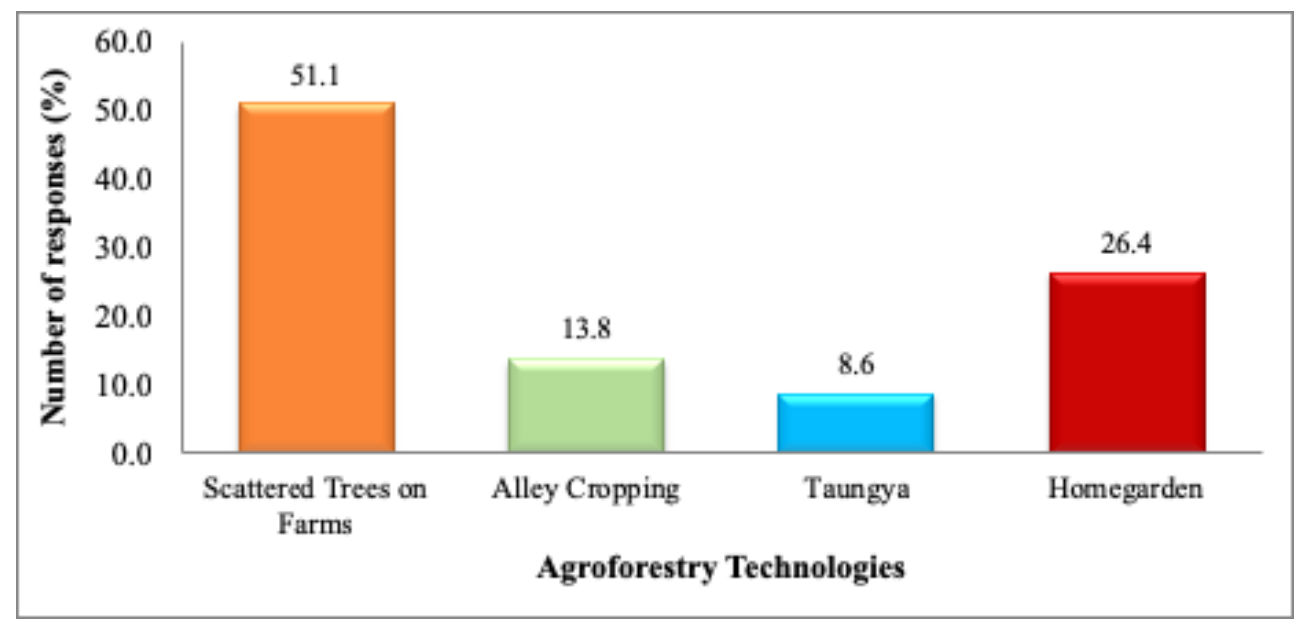

Source: Field survey (2018)

According to Alao and Shuaibu (2013), under scattered trees on farms, farmers (in most cases) retain or plant trees on their farmlands for income, food, soil and environmental improvement, and for shade during the harsh weather period. Similarly, the study revealed under this technology that, tree crops retained on the farmlands are usually naturally occurring trees or indigenous trees such as avocado pear (Persea Americana), orange (Citrus Sinensis), and kola (Cola Nitida). This technology is practiced hand-in-hand with shifting cultivation which has been practised in the Municipality for centuries. Respondents mentioned that when their fore-fathers were practicing shifting cultivation, they planted and retained the trees on the farms and the result is what they are reaping today. Some of the benefits of scattered/dispersed trees on farmlands as enumerated by respondents include; shade, enrichment of soil nutrients and organic matter, ability to withstand harsh conditions and the provision of commercial and subsistence values. A participant in a FGD in Japekrom, talked about the values of this technology that economic trees like avocado pear (Persea Americana) and orange (citrus sinensis) have been beneficial to her household income and food supplies. The woman indicated further that when they began farming, "the trees were there when we started farming and 
every season we harvest and get money from it". For these reasons, some farmers intentionally or unintentionally plant and leave tree crops such as mango, orange and avocado pear on farm lands.

Another technology practiced by respondents is alley cropping. Alley cropping is an agroforestry technology where woody plants are planted in rows together with annual crops planted in between the alleys. The findings of this study revealed that economic crops such as cashew (Anarcadium occidentale), cocoa (Theobroma cacao), orange (Citrus sinensis) and mango (Mangifera indica) were grown in alleys with food crops such as plantain (Musa sapientum), cassava (Manihot esculenta) and maize (Zea mays). The type of food crops and vegetables planted is, however the farmer's discretion. When asked why they practice alley cropping, some women mentioned they acted on the advice of extension officers that alley cropping helps overcome the overcrowding of trees and was influential in improving soil nutrients.

While some respondents hailed alley cropping, others expressed dislike for the technology. The later respondents stated that practicing alley cropping was a waste of fertile land and farm resources. One of such respondents intimated in an interview that, "alley cropping is a complex practice, for instance, extension officers tell us there should not be more than 80 trees on an acre of land, meanwhile I can sow more than that and prune some out". The same opinion was expressed by some discussants in FGDs across the four communities that the practice of alley cropping is somewhat tedious, hence their abstinence. This finding is in line with the observation of Vira et al. (2015), that alley cropping technique requires careful planning and considerable labour and management. Notwithstanding the technicalities, agroforestry literature espouses the practice of alley cropping because of its tremendous benefits for the environment and crop yield. Farmers dislike for the technology could probably be linked with a lack of orientation.

Another agroforestry technology, Taungya, was identified to be practiced by $8.6 \%$ of respondents in three communities: Japekrom, Gonasua and Kwameseikrom. A typical tree planted in this system is the Tectona grandis (teak) and it is spearheaded by the men. The main aim for the use of teak has been to regenerate their lost forest, while deriving sustenance values through intercropping. Farmers unanimously concluded in the FGDs that the Taungya system had been beneficial to their households and the environment. One farmer in Gonasua attested to this claim by revealing that the Taungya system helped the family recover their degraded land, "my father's cocoa farm burnt down in the 1983 fire outbreak and the land become a 'desert'. With advice from a relative who was an agriculturalist, we planted the land with Teak in order to reclaim the lost forest. Today, the place has become green again and we even sell some of the trees from time to time". 
Although the practice of Taungya is spearheaded by the men, women play a major part in the practice. The women are usually in charge of the planting of intercrops and vegetables as well as assisting in weeding. The only thing they do not do is to take that initial step in growing the trees - they claim such decisions are for the men, hence they do not consider themselves owners of the trees. This observation was supported by an officer at the Forest Service Division (FSD) in an interview that Taungya is practiced by the men because the women consider it as "men's work". It was further revealed that, the women are interested in trees and crops that bring them some income in the nearest future. As a result, they often go into the farming of cashew and cocoa, since they know that at least within three years of farming, they can reap some benefits.

Household interviews with the women revealed that indeed they preferred to plant tree species like cashew and cocoa, to the planting of Tectona grandis (teak) because these tree crops "give them fast money". According to a 37-year-old respondent at Faaman, there is no need farming a crop that would not bring immediate results, a perception that was also shared by almost all the women in the FGDs. Besides the monetary value, it also evident that cashew as a crop is more tolerant to harsh weather conditions and events such as bushfire and drought.

One important discovery, however, was that unlike the Modified Taungya System (MTS) (Abugre et al., 2010; Kalame, 2009), where farmers are given pieces of land by the government to cultivate food stuffs and preserve trees, taungya farmers in the study area were using their own (degraded) land for the practice, probably because they had little knowledge and awareness on regulations concerning the acquisition of reserved forests. This, however, implies that farmers have total control over the proceeds from the system; they enjoy full access to and control over the intercrops and vegetables as well as the trees.

The practice of home-garden was mainly observed among respondents in Kwameseikrom, Gonasua and Faaman. Home-gardens in the Municipality are characterised by the use of multipurpose trees (mainly; Citrus sinensis, Carica papaya and Mangifera indica), as well as food crops and all sorts of vegetables (Abelmoschus esculentus, Manihot esculenta, Zea mays, Musa sapientum, Capsicum annuum and Lycopersian esculentum). This description corresponds with the definition of home-garden by Bajpai et al. (2013) as a multi-species, multi-use small scale land use system in an ecosystem that are for the immediate needs of households with regards to their food, health and fuel. Respondents indicated that home-gardens are essential for the sustenance of their households in terms of food supplies and income. These findings also collaborate the submission of Galhena et al. (2013) that, home-gardens are auxiliary and not the core source of household consumption 
and income; occur on the small piece of land that even the poor can start. Owing to the essential use of home-gardens as a source of sustenance and nutritional supplement, they have been seen as a "treasure trove of biodiversity".

\section{Women's Participation in Major Farm Management Activities}

At the centre of agroforestry farming systems are women farmers who are generally responsible for managing trees and participating in various activities. Major farm management activities the study identified were land clearing, seed preparation, planting, weeding, spraying/fertilizer application and harvesting. The index of participation was used to assess the extent of women's participation in various farm activities. Across the four communities' women's participation in land clearing and preparation can be considered average. Specifically, the Index of Participation (IP) in Japekrom, Gonasua, Faaman and Kwameseikrom was average at $0.64,0.67$, and 0.62 and 0.62 , respectively (Table 5).

Table 5: Index of the level of participation for major farm management activities

\begin{tabular}{|c|c|c|c|c|}
\hline \multirow[t]{3}{*}{ Activity } & \multicolumn{4}{|c|}{ Index of Participation } \\
\hline & \multicolumn{4}{|c|}{ Communities } \\
\hline & Japekrom & Gonasua & Faaman & Kwameseikrom \\
\hline Land Clearing & 0.64 & 0.67 & 0.62 & 0.62 \\
\hline Seed Preparation & 0.72 & 0.75 & 0.82 & 0.84 \\
\hline Sowing/Planting & 0.87 & 0.94 & 0.94 & 0.93 \\
\hline Weeding & 0.83 & 0.88 & 0.81 & 0.91 \\
\hline Spraying & 0.33 & 0.25 & 0.40 & 0.33 \\
\hline Crop Protection & 0.54 & 0.78 & 0.67 & 0.73 \\
\hline Harvesting & 0.84 & 0.89 & 0.84 & 0.94 \\
\hline Drying & 0.78 & 0.88 & 0.80 & 0.93 \\
\hline Collection of by-products & 0.62 & 0.78 & 0.74 & 0.74 \\
\hline Storage of Produce & 0.77 & 0.87 & 0.78 & 0.86 \\
\hline
\end{tabular}

Source: Field survey (2018)

Less than half (39\%) of the women in all the four communities indicated that they 'often' participate in land clearing and preparation. These respondents are usually involved in the removal of stumps and general preparation of the land for the raising of mounds and planting. Clearing of primary/virgin forests was identified as difficult and a main responsibility of men (husbands, sons or hired labour). On the other hand, some women, all of whom were household heads revealed they usually take part in the clearing of forests that are without thick canopy trees or secondary 
forest. According to a 42-year-old respondent in Faaman, ever since her husband died she has been clearing forest all by herself because, "I do not have the financial resources to hire labour".

Another farm activity women highly participate in was seed sourcing and preparation. Seed sourcing involved the harvesting/picking of seeds from farms/ forest, purchasing of seeds for planting or seeking seeds from friends and relatives. There happened to be high participation in seed sourcing since a high number of the respondents (48\%), 'often' participated in this activity, while only $3 \%$ 'never' participated. The study revealed a high participation among respondents in Kwameseikrom (IP=0.84), with the least from Japekrom (IP=0.72) (Table 5). This reflects the observations of Enete and Amusa (2010a) and the FAO (2015) that women tend to be highly involved in activities like nursery tending and seedling preparation. The women further revealed that they were the ones that go to the shops to buy the seeds or at worse, follow fellow farmers for the seeds to plant. In the FGD in Kwameseikrom, the women indicated that although they may coown farms with their husbands, they source the vegetable seeds, while the men go in for the economic crops and food crops. The women revealed their husbands get the cocoa and cashew seedlings, as well as the other food crops from the extension officers, friends and relatives. This means that both men and women actively participate in seed sourcing activities but for different purposes.

Following seed sourcing and preparation, was sowing and/or planting, where women's participation was very high across all communities. Gonasua and Faaman had the same and the highest IP of 0.94 , while Japekrom recorded the IP of 0.87 (Table 5). Compared with other communities, participation was less in Japekrom because majority of the women indicated that they were involved in other income generation activities such as trading, dressmaking and hairdressing aside farming. Others were civil servants such as teachers and health workers. This makes it difficult for them to always be at the farm; hence they hire labourers to work for them. It was interesting to know, however, that no respondent had 'rarely' or 'never' participated in sowing and planting of seeds. Interviews with the women revealed that their husbands are equally active in the planting activity. Crops such as Anarcadium occidentale (Cashew), Theobroma cacao (cocoa), Dioscorea spp. (Yam) Manihot esculenta (Cassava) Xanthosoma sagittifolium (Cocoyam), Musa sapientum (plantain) Zea mays (Maize), Lycopersian esculentum (Tomato) Capsicum annuum (Pepper) Abelmoschus esculentus (Okro), Mangifera indica (Mango) and Arachis hypogaea (Groundnut) are sown or planted by both men and women.

Weeding is more necessary at the beginning of agroforestry systems, as such, weeding was identified as another important agroforestry management activity 
that most women do. This contradicts the position of Kiptot and Franzel (2012) that, when trees are integrated with food crops, no further weeding is necessary. The study found that, there is always weeding at the initial stages of planting before the intercrops begin to cover and women are at the core of activities as identified by the study. Across all the four communities, 51\% of women indicated that they 'always' participate in weeding. Meanwhile, women participating 'often' and 'never', reduced to $2.7 \%$ and $2 \%$ respectively.

The proportion of women that were participating in weeding in Kwameseikrom was high, with IP of 0.91, than in Japekrom (0.83), Gonasua (0.88) and Faaman (o.81). Weeding at the initial stages of planting is considered a woman's work, since it takes time and patience to weed around growing plants. Some men attested to this at an FGD in Japekrom. When asked why women are those weeding especially during the early stages of germination, there was unanimous conclusion from the women that they had the patience to take care of young plants. However in the FGDs organised in the other three communities, some of the men disagreed with the assertion that women are better managers of crops. These discussants posited that there is nothing their wives do on the farm that they cannot do. One of such men is a 56-year-old cocoa and cashew farmer in Kwameseikrom, who stated that he and his wife were both partakers in every farm management activity, "I clear the land; she helps in preparing it for planting. We all sow or plant the crops. She weeds, I weed. I apply chemicals (pesticides and weedicides) on the matured cocoa trees, she doesn't. When it comes to harvest, she is involved as much as I am. Also, in drying and storage, she is with me. The only thing I wouldn't allow her to do is to carry heavy loads home", he jokingly concluded.

The above revelation is a justification that women in male-headed households are supported in farm activities, maybe more than women in female-headed households. Although women in female-headed households might be supported by male members such as their sons or brothers, the general impression from discussants was that women in male-headed households had the upper hand.

The findings showed further that if there is one activity in which women participate always and often after sowing/planting, then it is harvesting and drying. Harvesting, ranges from picking of cashew nuts, cocoa pods, orange and mango, to harvesting of maize, pepper, yam and tomato, among other crops. Participation in harvesting was highest in Kwameseikrom (0.94). Although the IPs of the other communities were lower than the former [Faaman (0.84), Gonasua (o.89) and Japekrom (o.84)], generally there was high participation (Table 5). For drying of crops, some respondents were 'always' (34.8\%) and 'often' (49.5\%) participating. Hence, high participation in all communities; Japekrom (o.78), Gonsaua (o.88), 
Faaman (o.8o) and Kwameseikrom (o.93) (Table 5). In congruence to these findings, Catacutan and Naz (2015), on gender roles and decision-making in agroforestry adoption in Vietnam, revealed that women's participation is higher than men's in terms of harvesting and sorting crops.

Notwithstanding the high level of participation in the above-mentioned activities, the study noted that women's participation was very low in spraying, with Japekrom, Gonasua, Faaman and Kwameseikrom, all having low IPs of 0.33, 0.25, 0.40 and 0.33 respectively (Table 5). Across the four communities, more of the women (63.2\%) had 'never' participated in the spraying of crops, hence their low participation. Apparently, spraying is undertaken by the men. This agrees with the finding of Catacutan and $\mathrm{Naz}$ (2015) that men are more into laying out the farm, ploughing and spraying. At Faaman, the women revealed that, they usually apply fertilizers on pepper crops to ensure good yields but not spraying. Meanwhile, because the cash crops (e.g. cashew) are resistant to the harsh conditions of the weather, respondents indicated they hardly apply chemical fertilizers. However, use of inorganic fertilizer was mentioned in some communities. One respondent in Japekrom for instance, revealed that her household applied poultry waste on their farm after ploughing to make the soil more fertile.

\section{Women's Participation in Farm Management Decision-Making}

The study revealed that the role men play in decision-making is paramount, however, that is not to say there is avocation of women in household decisionmaking. Across the four communities, there was an indication that decisionmaking in the household regarding land preparation, type of tree or crop to farm, time of sowing, determination of farm size, purchase and sourcing of farm inputs, marketing of produce, farm credit and loans and crop rotation plans are jointly made by both men and women (i.e. in the case of male-headed households). Participation in decision-making in these activities can therefore be described as interactive participation (Agarwal, 2001), where women have the voice in and influence decision on the farm, leading to empowerment. The finding is in line with Catacutan and $\mathrm{Naz}$ (2015) in Vietnam, that joint decisions are made regarding crop varieties and tree species to plant.

The study also revealed that more often than not, households headed by females have the final decision-making roles, while in male-headed households, there are either no consultation, only consultation or consideration of opinions ${ }^{3}$. Interviews with respondents from female-headed households revealed that, they (women) take care

3 Women in male headed households don't make final decisions except in few instances. For instance if the husband has travelled, not a farmer or indisposed. 
of the household; therefore decisions (either tough or easy) were theirs to make. In a personal communication with a 49-year-old female household head at Gonasua, she stated that although she seeks opinions from friends, the final decision is made by her alone. Based on a study on gender roles and household decision-making for agriculture in Malawi, Meijera et al. (2015) posit that in sub-Saharan Africa, female-headed households solely make agricultural decisions and may consult their children on what to do on the farm.

The women in male-headed households revealed that decisions regarding land preparation and determination of farm size are usually made by the men, although their husbands do them the honour by seeking their opinions. The study revealed that $44.6 \%$ and $44.6 \%$ of respondents had their opinions considered on decisions concerning land preparation and determination of farm size respectively. This is an affirmation of Ojo's (2001) finding among Yoruba women in Nigeria that the men start farming and cater for the main farm activities with assistance from women.

On decision-making regarding determination of land size, some respondents in Japekrom (13.4\%) indicated that their husbands do not consult them when determining the farm size to establish. One of such respondents is a 35-year-old farmer at Kwameseikrom who posited that although her husband tells her about land preparation, she has no say in the size of the farm because farm labour for that activity is provided by the husband. The study also found a high participation of women in decision-making in the type of crop and time to plant. This stems from the fact that they are more knowledgeable, especially on deciding the kind of intercrops to use. Most women in male-headed households stated that although they are not the "final sayers", whatever they suggest to their husbands, is given due consideration. This implies that opinions of women in male-headed households on farm management activities are valued but subject to the approval of their husbands. This was expected, as Kiptot and Franzel (2012) stated that in the Kakamega District in Kenya, a wife is always expected to seek the consent of her husband before going ahead with any plans that may bring about any changes in the allocation of the household's resources.

\section{Constraints to the Practice of Agroforestry}

Based on data collected from households on their perceptions on the factors militating against their practice of agroforestry, six issues were categorised: lack of extension services and programmes, lack of access to agricultural NGOs, low technical know-how, lack of adequate information, multiple domestic responsibilities and lack of credit support and collateral security (Table 6). 
Table 6: Constraints to women's practice of agroforestry

\begin{tabular}{|l|l|l|l|}
\hline Constraint & \multicolumn{3}{|c|}{ Degree of Impact } \\
\hline & High & Medium & Low \\
\hline Lack of extension programmes & $153(75.0)$ & $49(24.5)$ & $1(0.5)$ \\
\hline Lack of awareness and access to NGOs & $143(70.1)$ & $59(28.9)$ & $2(1.0)$ \\
\hline Low technical know-how & $102(50.0)$ & $70(34.3)$ & $32(15.7)$ \\
\hline Lack of adequate information & $155(75.9)$ & $45(22.1)$ & $4(2.0)$ \\
\hline Multiple domestic responsibilities & $189(92.6)$ & $8(3.9)$ & $7(3.5)$ \\
\hline Lack of credit support and collateral security & $202(99.0)$ & $2(1.0)$ & - \\
\hline
\end{tabular}

Figures in parenthesis are percentages

Source: Field survey (2018)

Majority of the women (75\%) opined that inadequate extension service provision and training hindered their practice of agroforestry. Interviews with the women revealed that the agroforestry technology is quite technical and frequent visits by extension officers would have improved their farming. In Kwameseikrom, the women indicated that they had noticed a strange disease on cashew trees that affects and changes the colour of the leaves from green to dark-brown. This condition according to farmers affected tree fruiting, yet they did not know what exactly the problem was. This implies that if extension officers were visiting them, they would have known the problem and solutions would have been sought.

Inadequate information on agroforestry activities was noted by the study to work against women's practices of agroforestry. This was reported by $75.9 \%$ of household respondents. According to Enete and Amusa (2010b), institutional programmes do not consider the needs of women at the design and implementation stages of agricultural or agroforestry technology. In essence, institutional programmes do not seem to address women's special agricultural needs.

On women's multiple domestic responsibilities, the study revealed that women are involved in two main activities in the household; productive (such as food vending, petty trading, food preparation, fetching of water and fuel-wood) and reproductive activities (child birth, childcare and health care). These activities highly affect majority (92.6\%) of household respondents in their practice of agroforestry. This concern is supported by women farmers in cocoa based agroforestry communities in Nigeria, where multiple domestic responsibilities were reported as a major barrier to women's practice of cocoa agroforestry (Enete \& Amusa, 2010b). 
On economic constraints, almost all the respondents (99\%) reported inadequate credit support from relevant institutions and lack of collateral security as the major barrier to their practices of agroforestry. This agrees with a report by CIAS (2004) cited in Enete and Amusa (2010b) that women are faced with challenges that prevent them from making meaningful farming decisions in the household.

\section{CONCLUSION}

Agri-silviculture was identified as the main agroforestry system practiced in the study area along with technologies such as home-garden, scattered trees on farm lands, improved fallow, alley cropping and taungya. The common tree crops; cashew and cocoa are intercropped with plantain, cassava, maize, pepper, tomatoes and cocoyam. The study revealed that some socio-demographic characteristics of women such as the level of education and status in the household (married or single) influence women's practice of agroforestry. This study concludes that women are involved in agroforestry practice just like the men. Women do not only prefer food crops but also tree crops. Women's participation in major farming activities (seed sourcing/preparation, planting, weeding, harvesting, drying and storage) was high, except in land clearing and spraying, where their participation was average and low respectively. While women in female-headed households had the final decision-making roles, women in male-headed households had their opinions valued by their husbands on key farm decisions. Women's participation in decisionmaking can therefore be described across all the stages in Agarwal's (2001), ladder of participation: consultative participation, active specific participation, active participation, and interaction participation. Also, inadequate extension services, multiple domestic responsibilities and inadequate credit facilities are the major constraints to women's practice of agroforestry in the study area.

Since the study recognised that women's participation in agroforestry was high, it is recommended that MoFA and the Municipal Assembly should encourage women in other parts of the Municipality to get involved in agroforestry, since it does not only improve the environment but also boosts household income and food security. For women to have access to financial credit, government and relevant institutions such as MoFA should intervene to encourage the development of rural microcredit institutions with regulations friendly to women. To ensure that women get access to extension services, MoFA should train volunteer extension officers, majority of whom should be women. The study recommends further research to assess the economic benefits of agroforestry, in order to ascertain the influence of agroforestry on the livelihoods of women farmers in the area. 


\section{References}

Abugre, S. Asare, A.I and Anaba, T.A. (2010). Gender equity under themodified taungya system (MTS): A case of the Bechem forest district of Ghana. International Journal of Social Forestry, 3(2), pp. 134-150.

Adom, E. A. (2012). Gendered irrigation management: The case study of Ashaiman irrigation scheme in the greater Accra Region. Research in partial fulfilment of the requirements for obtaining the degree of Master of Arts in Development Studies, International Institute of Social Studies, The Hague, The Netherlands.

Agarwal, B. (2001). Participatory exclusions, community forestry, and gender: An analysis for south Asia and a conceptual framework. World Development, 29(10), pp.1623-648.

Ajayi, O., Akinnifesi, F., Mullila-Mitti, J, Dewolf, J, Matakala, P and Kwesiga, F. (2008). Adoption, profitability, impacts and scaling-up of agroforestry technologies in southern African countries. In Batish, D.R, Kohli, R.K, Jose, S. and Singh, H.P (Eds.), Ecological basis of agroforestry, Boca Raton, Florida: Taylor and Francis Group. Pp.343-360

Alao, J.S. and Shuaibu, R.B. (2013). Agroforestry practices and concepts in sustainable land use systems in Nigeria. Journal of Horticulture and Forestry, 5(10), pp. 156159.

Asfaw, S. and Maggio, G. (2015). Gender integration into climate-smart agriculture: Tools for data collection and analysis for research. Food and Agricultural Organisation, Rome.

Atangana, A., Khasa, D., Chang, S., and Degrande, A. (2014). Major land use issues in the tropics, and the history of agroforestry. Tropical Agroforestry, Springe Science+Business Media Dordrecht, pp. 23-33.

Bajpai, S., Sharma, A.K. and Kanungo, V.K. (2013). Traditional home gardens: A preserve of medicinal plants. International Journal of Herbal Medicine, 1(2), pp. 152-161.

Catacutan, D. and Naz, F. (2015). Gender roles, decision-making and challenges to agroforestry adoption in Northwest Vietnam. International Forestry Review, $17(4)$, pp. 22-32.

Deere, C.D., Alvarado, G.E. and Twyman, J. (2012). Gender inequality in asset ownership in Latin America: Female owners vs household heads. Development and Change, 43(2), pp. 505-530.

Degrande, A. and Arinloye D.D.A. (2014). Gender in agroforestry: Implications for Action Research. Nature and Fauna, 29(1), pp. 6-11. 
Dhakal, A., Cockfield, G. and Maraseni, T.N. (2015). Deriving an index of adoption and assessing factors affecting adoption of an agroforestry-based farming system in Dhanusha District, Nepal. Agroforest System.

Edinam, K.G., Hassan, B.A. and Mawutor, K.G. (2013). Analysis of socio-economic conditions influencing adoption of agroforestry practices. International Journal of Agriculture and Forestry, 3(4): pp. 178-184.

Enete, A.A. and Amusa, T.A. (2010a). Determinants of women's contribution to farming decisions in cocoa based agroforestry households of Ekiti State, Nigeria. Field Action Science Report, 4, pp. 1-6.

Enete, A.A. and Amusa, T.A. (2010b). Contribution of men and women to farming decisions in cocoa based agroforestry households of Ekiti State, Nigeria. Tropicultura, 28(2), pp. 77-83.

FAO (2010). Climate-smart agriculture: Policies, practices and financing for food security, adaptation and mitigation, FAO, Rome.

FAO. (2015). Understanding women's participation in forestry in Vietnam. Policy brief, Thailand. Food and Agricultural Organisation (FAO) (2015).

Galhena, D.H., Freed, R. and Maredia, K.M. (2013). Home gardens: a promising approach to enhance household food security and wellbeing. Agriculture \& Food Security, 2:8

Gentle, P., Thwaites R.., Race, D., and Kim, A. (2014). Differential impacts of climate change on communities in the middle hills region of Nepal. Nat Hazards, Springer Science+Business Media Dordrecht.

Ghana Statistical Service (GSS) (2011). Statistical service releases http://www.ghana. gov.gh/index.php?option=com_content \&view=artice\&id=5286:ghana-

Ghana Statistical Service (GSS) (2014). 2010 population and housing census. District analytical report, Jaman South District. GSS, Accra.

IPCC, (2012). "Glossary of terms," a special report of working groups I and II of the intergovernmental panel on climate change (IPCC): Managing the risks of Extreme events and disasters to advance. Climate change adaptation, Field, C.B., V. Barros, T.F. Stocker, D. Qin, D.J. Dokken, K.L. Ebi, M.D. Mastrandrea, K.J. Mach, G.

Jaman South Municipal Assembly (2010). 2010-2013 district medium-term development plan. Jaman South Municipal Assembly, Drobo.

Johnson R.B., Onwuegbuzie A.J., Turner L.A. (2007). Toward a definition of mixed methods research. J Mix Methods Res, 1(2), pp. 112-133. 
Kalame, F.B. (2009). The modified taungya system in Ghana's transitional zone. ETFRN News 50 (November)

Kamnap, P. (2003). The impact of local people's participation on forest concession management in Cambodia: A case study of the colexim forest concession company in Kampong Thom Province. Master thesis submitted to Asian Institute of Technology School of Environment, Resources and Development Thailand. web. idrc.ca/uploads/user S/10936165071 PhanKamnap Thesis.doc

Kilic, T., Palacios-Lopez, A., Goldstein, M., (2014). Caught in a productivity trap: A distributional perspective on gender differences in Malawian agriculture. World Development, 70, 416-463

Kinkingninhoun-Medagbe, F., Diagne, A., Simtowe, F., Abgoh-Noameshie, A., Adegbola, P., 2010. Gender discrimination and its impact on income, productivity, and technical efficiency: Evidence from Benin, Agr. Hum, 27(1), 57-69.

Kiptot, E. and Franzel, S. (2012). Gender and agroforestry in Africa: a review of women's participation. Agroforestry Systems, 84(1), pp. 35-58.

Mauricio, R.M., Ribeiro, S.R., Paciullo, D.S.C., Cangussu, M.A., Murgueitio, E., Chara, J., Estrada, M.X.F. (2019). Silvopastroal systems in Latin America for biodiversity, environmental and socioeconomic improvements. In, Agroecosystem Diversity: Reconciling Contemporary Agriculture and Environmental Quality. Elsevier. pp. 287-297.

Meijera, S.S., Gudeta W.S, Godfrey K., Delia C. and Maarten N., (2015). The role of gender and kinship structure in household decision-making for agriculture and tree planting in Malawi. Journal of Gender, Agriculture and Food Security, 1(1), pp. 54-76.

Mulugeta, M. and Amsalu, T. (2014). Gender, participation and decision-making process in farming activities: The case of Yilman Densa District, Amhara Region, Ethiopia. Journal of Economics and Sustainable Development, 5(1), pp. 28-34.

Ojo O. (2001). Yoruba women, cash crop production and the colonial State; 1920-1957. A paper presented at the conference on Atlantic crossings: Women's voice, women's stories from the Caribbean and the Nigerian Hinterland. Dartmouth College, May 18- 20.

Opoku-Mensah, A. (2015). Land use analysis for agroforestry interventions in the Asunafo North District of the Brong Ahafo Region, Ghana. In MSc thesis submitted to the Department of Agroforestry, Kwame Nkrumah University of Science and Technology, Kumasi, Ghana. 
Parwada, C., Gadzirayi, C.T., Muriritirwa, W.T. and Mwenye, D (2010). Adoption of agro forestry technologies among smallholder farmers: A case of Zimbabwe. Journal of Development and Agricultural Economics, 2(10), pp. 351-358

Poudyal, M. (2009). Tree tenure in agroforestry parklands: Implications for the management, utilisation and ecology of shea and locust bean trees in northern ghana. In PhD Thesis University of York, England.

Rogan, M. (2013). Alternative definitions of headship and the "feminisation" of income poverty in post-apartheid South Africa. The Journal of Development Studies, 49(10), pp. 1344-1357.

Satterthwaite, D. (2007). The transition to a predominantly urban world and its underpinnings. London, UK: IIED.

Smith, J. (2010). Agroforestry: Reconciling production with protection of the environment. The Organic Research Centre.

Vira, B. Wildburger, C. and Mansourian, S. (2015). Forests and food: Addressing hunger and nutrition across sustainable landscapes. Cambridge, UK: Open Book Publishers.

World Bank (WB), (2012). World development report 2012: Gender equality and development. The World Bank, Washington, DC. 